\title{
Religion som utfordring \\ i et multikulturelt samfunn
}

Terje Ahmad Frostad

Volda University College

frostad22@hotmail.com 


\section{Innledning}

Norge har som en demokratisk stat i oppgave å ivareta sine borgere på best mulig måte. Det demokratiske system byr på utfordringer knyttet til minoriteters rettigheter i og med at de alltid vil være avhengige av majoritetens godkjenning. I denne artikkelen vil jeg belyse noen av utfordringene religiøse minoriteter kan oppleve og hvilke utfordringer det norske samfunn stilles ovenfor i møtet med disse religiøse minoritetene. Som utgangspunkt for denne artikkelen har jeg arbeidet ut fra temaet "Religion som utfordring i et multikulturelt samfunn."1 Jeg ønsker å diskutere hvilke utfordringer det multikulturelle Norge stilles overfor ved tilstedeværelsen av ulike religioner og hvilke utfordringer utøvere av minoritetsreligioner kan møte i det norske samfunnet.

Jeg vil innledningsvis presentere ett av mange eksempler som viser hvilke utfordringer som kan oppstå knyttet til tilstedeværelsen av ulike religioner. For at kjøtt skal bli kosher (lovlig for jøder) er det visse regler som må følges. Blant annet innebærer dette at dyret ikke kan bedøves før slakting. Dette bryter med norsk lov om dyrevelferd. Det finnes mange lignende eksempler. Slike forhold kan representere utfordringer på samfunnsnivå (religiøse rettigheter sett opp mot dyrevelferd), på gruppenivå (hvordan oppfylle religiøse behov) og på individnivå (kan jeg støtte et samfunn som ikke verdsetter mine verdier?). Gjennom artikkelen ønsker jeg å belyse flere slike utfordringer, se dem fra flere sider og drøfte dem opp mot hverandre.

\section{Begrepsavklaringer}

For å klargjøre hva jeg legger i de ulike begrepene har jeg valgt å se på begrep for begrep, og vil gjennom teori og refleksjon redegjøre for hvilken betydning av begrepene jeg vil ha som utgangspunkt for denne artikkelen og som ligger til grunn for utformingen av mine problemstillinger.

\section{Multikulturelt samfunn}

For å forstå 'multikulturelt samfunn' som begrep er det viktig å forstå de ulike aspektene av begrepet. Kulturbegrepet er et komplekst begrep som vanskelig lar seg definere presist, men det betyr ikke at det ikke er gjort mange fors $\varnothing \mathrm{k}$. Begrepet kultur brukes også på flere måter. Jeg vil i denne artikkelen forholde meg til en antropologisk forståelse av begrepet. Krogseth (2009: 32) definerer kultur som "den komplekse helhet av forestillinger og praksisformer som fortolkende og forandrende videreføres innenfor et fellesskap". Han hevder videre at faren med slike definisjoner er at de blir så generelle at de blir overfladiske og langt på vei intetsigende. I denne artikkelen vil jeg ikke begi meg inn på en dypere diskusjon omkring hva kultur er, men vil ta utgangspunkt i definisjonen ovenfor.

I likhet med kultur er også et 'samfunn' et begrep som har flere bruksformer. Vi kan for eksempel snakke om lokalsamfunn, en selvstendig folkegruppe med et eget landområde og levesett eller det globale verdenssamfunnet. I denne artikkelen vil jeg ta utgangspunktet $\mathrm{i}$ nasjonalstaten som et eget samfunn.

Når man da setter sammen disse begrepene og i tillegg inkluderer at det skal bestå av flere kulturer, er det klart at det er et begrep som kan oppfattes på mange ulike måter. Med multikulturelt samfunn vil jeg derfor forholde meg til Norge som et felles samfunn

1 Artikkelen er en bearbeidet versjon av en prosessoppgave med samme tittel i emnet Den sekulære skulen i eit religiøst og kulturelt mangfald i masterprogram i Samfunnsplanlegging og ledelse ved Høgskolen i Volda våren 2013. 
bestående av mange mer eller mindre ulike kulturer innenfor sine grenser. Jeg tar utgangspunkt $\mathrm{i}$ at de ulike kulturene som danner det norske multikulturelle samfunnet tildels er knyttet til ulike religioner. Dette kan hevdes å være generaliserende, men jeg har allikevel valgt denne avgrensningen for å legge frem synspunkter som belyser utfordringer knyttet til tilstedeværelsen av ulike religioner i samfunnet og de ulike religioners utfordringer knyttet til møtet med samfunnet.

\section{Religion}

I følge Otto Krogseth (2009) kan religionsbegrepet sies å være noe smalere enn kulturbegrepet, men de er begge begreper av andre orden, det vil si at de ikke er avbildninger av en foreliggende størrelse og har dermed ikke noen enkel definisjon som alle

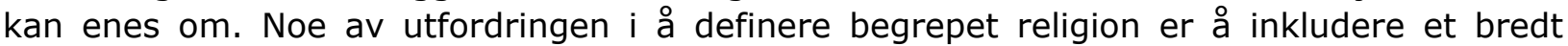
spekter av trosretninger med utallige varianter og samtidig avgrense på en måte som utelukker øvrige forhold som kulturelle tradisjoner. Krogseth hevder at kultur og religion er hyperkomplekse, vanskelig definerbare, overlappende og tett integrerte størrelser. Forskning innen kultur og religion kan dermed dra nytte av hverandres metoder i sitt arbeid (Krogseth 2009: 42-45). I denne artikkelen vil jeg ikke begi meg inn på en dypere diskusjon rundt religionsbegrepet, men vil i min bruk av begrepet omtale forhold knyttet til registrerte livssyns- og trossamfunn. Jeg forholder meg dermed til samme ramme som benyttes i offentlige dokumenter.

\section{Integrering}

'Integrering' er et begrep som står sentralt i en tekst om utfordringer knyttet til religion i det multikulturelle samfunn. I stortingsmeldinga "Mangfold gjennom inkludering og deltagelse" (Arbeidsdepartementet, 2004) hevdes det at noe av problemet med begrepet integrering er at det ikke finnes noen enhetlig oppfatning eller definisjon. Segregering og assimilering er nyttige begreper for å forstå hva regjeringen legger i integrering. Segregering kan være sosial eller fysisk og kan føre til liten eller ingen kontakt mellom ulike sosiale og etniske miljøer. Assimilering kan sees som motsetning til segregering; at innvandrere oppgir sin egen kultur, tradisjon og levesett for å bli lik majoriteten er et eksempel på assimilering. Regjeringens forståelse av begrepet integrering står i kontrast til både segregering og assimilering. Ut fra dette ser jeg på integrering som en prosess $i$ retning av et åpent samfunn hvor alle har like rettigheter, muligheter og plikter, samt at dette er respektert og sett på som verdifullt av majoritet så vel som minoritet.

\section{Samfunnets utfordringer knyttet til religion i det multikulturelle samfunn}

For å finne ut av hvilke utfordringer samfunnet møter har jeg hovedsakelig valgt å forholde meg til offentlige kilder og à drøfte disse ut fra relevant teori. I 2010 ble Tros- og livssynspolitisk utvalg (Stålsettutvalget) oppnevnt for å legge fram forslag til en mer helhetlig tros- og livssynspolitikk. "Utvalgets mandat slår fast at statens fremste oppgave i tros- og livssynspolitikken er å sikre og beskytte tros- og livssynsfriheten. Utvalget ble også bedt om å legge til grunn at staten fortsatt skal føre en aktivt støttende tros- og livssynspolitikk." (Kulturdepartementet 2013: 2.1.). Norge som stat ønsker altså å føre en aktivt støttende tros- og livssynspolitikk samtidig som ulike tros- og livssyn blir sett som likeverdige. 
I boka "The Multicultural Riddle" (Baumann 1999: 41-55) hevdes det at nasjonalstater ikke er religiøst nøytrale. Bauman trekker frem ulike eksempler på hvordan en religions symboler, helligdager og verdier har betydelig mer tilstedeværelse enn andre religioner i ulike land. Han trekker frem forbudet mot hodeplagg i den franske skolen som Baumann, sannsynligvis med god grunn, hevder er innført for à begrense muslimske jenters mulighet til å bruke hijab. På den amerikanske dollarseddelen står det "In God we trust". I Norge er det også lett å finne eksempler på at kristendommen har større påvirkning på det norske samfunnet som helhet enn øvrige tros- og livssyn. FN har også gjentatte ganger kritisert Norge for mangel på religionsfrihet, blant annet KRL faget (Øgstad 2006).

Baumann (1999:. 69) hevder også at religioner får nye utrykk i nye situasjoner. Baumann viser til et eksempel fra den Sentrale Moskeen i Paris som i mellomkrigstiden representerte Frankrikes storhet og tilstedeværelse $\mathrm{i}$ en fjerdedel av den muslimske verden. Etter kolonienes selvstendighet og økt innvandring har moskeen blitt et symbol på en religiøs minoritet og noe fremmed. Med dette i tankene vil en kontinuerlig dialog og vurdering av religiøse fellesskaps behov i samfunnet være avgjørende for à henge med i samfunnsutviklingen og for å ha et inkluderende samfunn.

\section{Religion i hverdagen}

I tidligere tider var stemmerett og andre rettigheter forbeholdt landenes elite. Nå har det store flertallet av en stats innbyggere stemmerett og rett på velferdsordninger fra den nasjonen de er bosatt i. Når Aristoteles snakket om (med)borgere var han opptatt av deres plikter. I det moderne samfunn har rettigheter nå kommet i fokus (Jackson, 2003). De fleste medborgere i Norge kan regnes som aktive medlemmer av det norske samfunnet. I Norge (og de fleste andre stater) er dette rettigheter som er uavhengige av medborgernes religion. Ut fra dette kan det hevdes at et fungerende demokrati må ha regler som likestiller sine borgere uavhengig av religion, kultur, etnisitet og botid i landet.

I følge Skeie (2003) har den offisielle norske immigrasjonspolitikk integrasjon som mål. Dette står i motsetning til segregering eller assimilering. Det er derimot ikke like klart hva det vil si å være integrert. Skeie hevder at ingen blir integrert uten at de selv aksepterer å bli integrert. Dersom man tar utgangspunkt i denne påstanden står Norge overfor en omfattende utfordring for å oppnå målet om integrering. Det vil da kunne hevdes at for $\stackrel{\circ}{\circ}$ være integrert må en kjenne et samsvar mellom egne verdier og de verdiene som finnes $\mathrm{i}$ det norske samfunnet. For religiøse personer vil muligheten til à praktisere sin religion kunne være av avgjørende betydning. A kunne benytte seg av religiøse plagg og symboler, à kunne spise kjøtt slaktet innenfor landets grenser, å kunne feire religiøse høytider og at ens tro blir sett på som like verdifull som andres i skolen og det offentlige rom forøvrig vil kunne være av avgjørende betydning for om et menneske vil føle seg integrert.

Barne- og ungsomsskolefaget Kristendom, Religion og Livssyn (KRL) fikk over tid en del kritikk for manglende likeverd mellom ulike tros- og livssyn. Kritikken førte til at saken ble lagt frem for Den Europeiske Menneskerettighetsdomstolen. I juni 2007 avsa domstolen en kjennelse om at KRL-faget bryter med den Europeiske menneskerettighetskonvensjonen. Som følge av dette har fagets navn blitt endret til Religion, Livssyn og Etikk (RLE) og lovendringer har gjort at fagets innhold er endret for å sikre at ulike tros- og livssyn blir behandlet med likeverd. Alle tros- og livssyn skal behandles med objektivitet, og på en kritisk og pluralistisk måte i skolen (Justis- og Beredskapsdepartementet; 2009). Den nye regjeringen har vedtatt en endring av fagets navn til Kristendom, Religion, Livssyn og Etikk (KRLE). Det er ikke planer om å endre kompetansemålene for faget, men en presisering av hvor stor andel av undervisningen som skal vies kristendommen (55\%). Siden dette ikke ennå er iverksatt ønsker jeg ikke å kommentere dette utover å stille spørsmålstegn ved om 
navneendringen indirekte hever kristendom over de andre religionene $\mathrm{i}$ og med at kristendom skilles ut fra religionsbegrepet. Ved å si kristendom og religion kan det hevdes at kristendom ikke inkluderes i religionsbegrepet. Det kan muligens oppleves som forskjellsbehandling av religioners status.

En kan hevde at alternativet til å tilpasse lovverk til den multikulturelle tilstedeværelsen kan være et samfunn hvor likhet fremdyrkes og som fremmer assimilering. Det kan hevdes at den offentlige skole har brukt KRL-faget som et middel til å fremme tradisjonell norsk tro og kultur på bekostning av andre livssyn og kulturer. Med overgangen til RLE har dette endret seg. Lærere skal vise alle religioner den samme respekt og være nøytrale i spørsmålet om religioners sannhet. Døving (2010) fremmer synspunkter om at det kanskje ikke er den tradisjonelle norske tro som fremmes, men derimot et sekulært livssyn. Hun viser til Casanovas omtale av vesteuropeisk religiøsitet. Casanova hevder at den vesteuropeiske majoritetsbefolkning enten er "troende uten tilhørighet" eller de kan ha en "religiøs tilhørighet uten tro". Hun skriver videre at i Europa er modernitet og fremskritt tett knyttet sammen med sekularitet og at religiøse utrykk i langt større grad enn i USA oppfattes som fundamentalisme. Hun nevner også artikkelen "Den sekulære ekstremisten" (Rana 2008), vinneren av en kronikkkonkurranse som omtalte problemer knyttet til å uttale seg på religiøst grunnlag i offentligheten, og reaksjonene som fulgte kronikken som et eksempel på sekularismens sterke rolle i samfunnet (Døving 2010). Ut fra dette kan en hevde at skolen benyttes til assimilering til et sekularistisk livssyn. Dette synet kan styrkes av formuleringer i de ulike læreplanene. I innledningen til fagplanen til KRL sto det at faget skulle ivareta den enkelte elevs identitet ut fra egen tilhørighet, samtidig som det skulle fremme dialog i en felles kultur (Nasjonalt Læremiddelsenter: 89-90). I den nyere RLE planen er dette moderert til at "både individuelle og lokale hensyn bør ivaretas" og det er omtalt i et avsnitt som omhandler at elevene ikke skal oppleve å bli utsatt for utøvelse av en annen religion eller livssyn (Utdanningsdirektoratet 2008).

Bruk av religiøse plagg og symboler er også et tema som gjentatte ganger har vært oppe til diskusjon. I 2008 vurderte Likestillings og diskrimineringsombudet en sak der Norgesbuss AS nektet en bussjåfør å bruke turban. Mannen ønsket å følge sine plikter som sikh, deriblant å bruke turban. Norgesbuss AS mente at uniform var viktig for identifikasjon av sjåføren og at den innebar myndighetseffekt. Likestillings- og diskrimineringsombudet mente at busselskapet handlet i strid med forbudet mot indirekte diskriminering på grunn av religion. Det ble vist til at andre arbeidsgivere som f.eks. Forsvaret har løst identifikasjonsproblemet ved å tilpasse uniformen slik at religiøse hodeplagg kan benyttes (Likestillings- og diskrimineringsombudet, 2008). I følge "Bestemmelser om felles uniformsregler i Forsvaret" (Forsvaret 2012) punkt 3.5 er religiøse symboler tillatt brukt til uniform i Forsvaret. Personer tilhørende kristendom, islam, sikhisme og jødedom har egne gjeldene regler for hva som er tillatt. For eksempel kan kristne kvinner dekke til håret under gudstjeneste og muslimske kvinner bruke langermet skjorte selv om de øvrige soldatene benytter kortermet skjorte.

Når det gjelder religiøse krav til slaktemetoder er utfordringene knyttet til dette hovedsakelig i forhold til Norges lovverk knyttet til bedøvelse i forbindelse med slakting sett opp mot religiøse krav. "Dyr som eies eller på annen måte holdes i menneskelig varetekt, skal bedøves før avliving." (Dyrevelferdsloven 2009: §12). I muslimsk og jødisk tradisjon er bedøving før slakting ikke vanlig og religionene har beskrivelser som omtaler hva som gjør kjøttet lovlig (halal for muslimer og kosher for jøder) å spise for tilhørerne av religionen. Begge religionene krever at dyret blir avlivet ved at strupen skjæres over. De fleste muslimer vil kunne tillate at dyret er bedøvet før strupen skjæres over og det finnes flere slakterier i Norge som er godkjent av Islamsk Råd Norge til å slakte og selge produkter merket som halal. For ortodokse jøder vil derimot ikke bedøvelse før slakt kunne 
godkjennes for at kjøttet skal bli kosher (Kulturdepartementet 2013). En kan hevde at samfunnets utfordring knyttet til dette er å finne balansen mellom dyrevelferd og religiøse rettigheter.

Inkludering er et begrep som enkelte ganger erstatter begrepet integrering i omtale av tiltak for à motvirke assimilering og segregering. Inkludering innebærer at noen aktivt må handle gjennom å åpne opp og invitere inn. Regjeringen mener at dette ansvaret normalt hviler på majoriteten og at det er ønskelig med et inkluderende samfunn uten sosial utstøting, marginalisering og ulike muligheter (Arbeidsdepartementet 2004). Hvis man ser på holdningene den norske befolkning har til religiøst mangfold kan man få en forståelse av hvorfor det er knyttet utfordringer til religion i det multikulturelle samfunn. Kun $45 \%$ av befolkningen er enig eller sterkt enig $i$ at alle religiøse grupper i Norge bør ha like rettigheter og hele $35 \%$ er uenig eller sterkt uenig i denne påstanden. Når det gjelder respekt for ulike religioner er tallene høyere: $76 \%$ av befolkningen er enig eller sterkt enig i at vi må respektere alle religioner, mens det her kun er $12 \%$ som er uenig eller sterkt uenig (Schmidt 2010). Selv om tallene knyttet til respekt for religioner er mer inkluderende enn når det gjelder rettigheter, kan det hevdes at selv 12 \% er et høyt tall når det betegner dem som er uenige i at alle bør behandles med respekt. Dette er holdninger som kan skape store utfordringer i integreringsarbeidet som staten har som uttalt mål.

Når en ser på de ulike eksemplene nevnt ovenfor og samtidig tenker på holdningene personer med annen religiøsitet møter hver dag, er det kanskje forståelig at noen ikke ønsker å integreres. Skal en oppfylle målet om full integrering vil det være viktig å gjøre grundige vurderinger av hva som er rett og galt ut fra en tanke om likeverd for alle religioner samtidig som en driver holdningsskapende arbeid. Ett eksempel på slikt arbeid er Stålsettutvalget som har bidratt til å påpeke utfordringer knyttet til religion i en utvidet sammenheng, samt kommet med forslag til hvordan disse utfordringene kan løses.

\section{Blasfemi i forhold til ytringsfrihet}

Karikaturstriden, publisering av karikaturtegninger av muslimenes viktigste profet Muhammed, i Jyllandsposten i 2005, har aktualisert utfordringer knyttet til ytringsfrihet sett opp mot blasfemi. Straffelovens $§ 142$ omtaler blasfemi på følgende måte:

Den som i ord eller handling offentlig forhåner eller på en krenkende eller sårende måte viser ringeakt for nogen trosbekjennelse hvis utøvelse her i riket er tillatt eller noget lovlig her bestående religionssamfunds troslærdommer eller gudsdyrkelse, eller som medvirker hertil, straffes med bøter eller med hefte eller fengsel inntil 6 måneder.

Det er over 100 år siden noen ble dømt for blasfemi og bestemmelsen anses derfor som en "sovende" paragraf og er i en NOU (Justis- og Beredskapsdepartementet 1999) anbefalt fjernet med begrunnelse i at blant annet straffelovens $\S 135$ beskytter en person eller en folkegruppe mot forhånelse på grunn av deres trosbekjennelse.

I de store protestene som oppsto i Norge og i øvrige deler av verden som følge av karikaturene av Profeten Muhammed, møtte samfunnet på en utfordring knyttet til det religiøse mangfold. Innen de fleste retninger av islam er det et bildeforbud blant annet knyttet til avbilding av profeter. Muslimer generelt viser forståelse for at kristne har et annet forhold til dette og derfor avbilder Jesus (som i islam er en viktig profet som dermed heller ikke skal avbildes). Sinnet oppsto som følge av det som ble oppfattet som en provokasjon uten annen hensikt enn å håne det muslimer ser på som hellig. Det kan hevdes at formålet

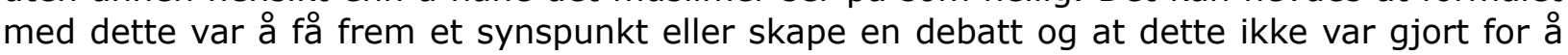


håne noens tro. Balansegangen mellom å verne folket mot krenkelser uten å begrense folkets ytringsfrihet viser seg å være utfordrende i et multikulturelt samfunn hvor folks opplevelse av hva som er hellig varierer stort. Som Fabian Stang sa i sin appell under en demonstrasjon som følge av filmen som hånet Profeten Muhammed i september 2012 (Snoen 2012):

Noen har sagt at jeg er veldig uenig i det du sier, men jeg vil kjempe inntil min død for din rett til å si det. Dessverre er det noen som misbruker ytringsfriheten til à krenke andres følelser. Slikt ynkelig misbruk må møtes med mot og samhold. Det er forståelig å reagere med sinne og raseri når det kjæreste vi har blir hånet og ydmyket, men vi skal aldri svare på slik oppførsel med vold.

Stang understreket senere lovligheten av filmen og argumentete for at ytringsfriheten ikke bør innskrenkes, men at en bør ha en positiv hensikt med sine ytringer.

\section{Stereotypisering}

En annen utfordring knyttet til det multikulturelle samfunnet er å se individ fremfor grupper. Etter terroren rammet Norge den 22. juli 2011 ble muslimer i flere tilfeller mistenkeliggjort i perioden frem til det kom frem hvem som sto bak.

Etter terrorangrepet kom noen av de mørkeste holdningene frem, sa diskrimineringsombud Sunniva Ørstavik til Aftenposten i romjulen. Hun fortsatte: - Vi har mye felles historie etter 22. juli. Fordommer, hets og fysiske angrep, som spesielt muslimer opplevde i timene før gjerningsmannen ble kjent, er også en del av denne historien. Slikt hat må vi bekjempe (Storhaug 2012).

Rapporten "Diskrimineringens omfang og årsaker. Etniske minoriteters tilgang til norsk arbeidsliv" (Midtbøen \& Rogstad 2012) viser at personer med ikke typisk norske navn blir innkalt til jobbintervju betydelig sjeldnere enn de med typisk norske navn dersom de har like kvalifikasjoner. Dette sier ikke direkte noe om utfordringer knyttet til religion, men indirekte kan det hevdes at de med annen religiøs tilhørighet enn majoritetsbefolkningen kan ha vanskeligere tilgang til arbeidsmarkedet enn majoritetsbefolkningen.

\section{Religiøse individers utfordringer i det norske samfunnet}

Hvilke konkrete utfordringer utøvere av ulike religioner møter i det norske samfunnet er selvfølgelig individuelt og varierer fra person til person og ut fra religion, religiøs tilknytning og kontekst. Og som Baumann (1999: 97-106) nevner er det viktig à huske at alle mennesker er individer. En tilpasning av regler for å gjøre livet lettere for muslimer treffer ikke nødvendigvis alle muslimer. Det finnes minoriteter innad i minoritetene som også er viktige å ivareta. Jeg ønsker allikevel å se mest på generelle utfordringer og konkretisere disse med eksempler fra ulike livssyns- og trossamfunn.

Alle norske helligdager har bakgrunn i kristen tradisjon. Arbeidsuken med søndag som den dagen hvor de fleste butikker er stengt, vitner også om kristne tradisjoner. For muslimer er fredag den helligste dagen, mens for jøder er lørdag den viktigste dagen for religionsutøvelse. Likevel har religiøse minoriteter i Norge stort sett bedre rettigheter enn i øvige deler av verden når det gjelder helligdager. I grunnskolen har man rett på fri ved religiøse helligdager og det er ingen begrensing $\mathrm{i}$ antall dager. I videregående skole og $\mathrm{i}$ arbeidslivet er to dager et minstekrav. Men arbeidstakerne har som oftest mulighet til å få mer ved søknad om velferdspermisjon med eller uten Iønn. Forsvaret viser seg også på dette området svært liberale og tillater et antall dager tilsvarende det antall helligdager det 
er i samfunnet. De gir også permisjoner til pilegrimsreiser med forbehold om lokale tjenesteforhold, øvelser og krig (Kulturdepartementet 2013). Allikevel kan regelverket være utfordrende for dem som for eksempel av religiøse årsaker ikke ønsker å arbeide på sabbaten. En adventist som ikke ønsket å jobbe på sabbaten ble i 2011 nektet dagpenger etter at han krysset av i søknadsskjemaet til NAV at han ikke var villig til å ta ethvert arbeid (Kulturdepartementet 2013).

Når det gjelder skolegang har overgangen fra KRL til RLE tilsynelatende redusert misnøyen blant religiøse minoriteter. Med utvidet rett til fritak og krav om kvalitativ likestilling innen religionsundervisningen har forholdene bedret seg. En kan hevde at med retten til fritak vil de fleste minoriteter få oppfylt sitt ønske om ikke å bli påtvunget andre verdier enn de en selv verdsetter, selv om enkelte kanskje kunne ønske seg en ordning mer lik den belgiske hvor en kan velge mellom undervisning fra ulike registrerte tros- og livssynssamfunn (Kulturdepartementet 2013).

Større utfordringer kan det derimot være knyttet til bruken av religiøse symboler og plagg. Ut fra religiøse minoriteters synspunkt kan en hevde at det er en ulik behandling knyttet til dette. Kristne symboler finnes mange steder i samfunnet, blant annet i flagget, riksvåpenet og offentlige bygg og monumenter. "Gud bevare kongen og fedrelandet" brukes blant annet i forsvaret. Tilstedeværelsen av disse kristne symbolene og symbolikk i det offentlige rom vil kunne virke provoserende når det ikke tillates tilsvarende bruk av andre religioners symboler. Særlig når det gjelder politi og dommere har dette vært debattert. I Norge er det ikke tillatt å bruke hijab eller turban til politiuniform, en vurdering basert på symbolikk og ikke ut fra praktiske hensyn. Dette har blant annet blitt kritisert av likestillings- og diskrimineringsombudet, særlig med tanke på at politihøyskolen har et uttalt ønske om å rekruttere personer med minoritetsbakgrunn. Flere land har tillatt dette, blant annet Sverige og England. I England har de også fritak fra krav om hjelm på motorsykkel og på arbeidsplasser for sikher. Stålsettutvalget mener dette ikke er nødvendig med slike tiltak pr dags dato fordi det finnes gode alternativer til motorsykkeltransport og at det heller bør finnes praktiske løsninger som kan kombinere sikkerhetskrav og sikhenes ønsker på arbeidsplasser (Kulturdepartementet 2013). Slik lovverket er nå kan det hevdes å hindre

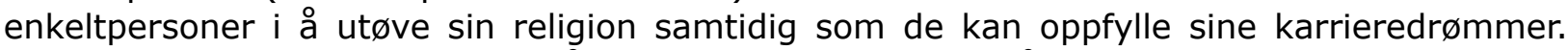
Slike begrensninger kan hevdes å ha en negativ virkning på langt flere enn kun de som er aktuelle for slike jobber, gjennom at de føler en forskjellsbehandling ut fra religion. Som nevnt ovenfor finnes det også minoriteter blant minoritetene som også er viktig å ivareta. Vil tilpasninger av uniformsreglementet i forsvaret legge ekstra press på muslimske kvinner om å bære hijab selv om de i utgangspunktet ikke ønsker dette? Det vil åpenbart være viktig at reglene gir mulighet for tilpasning, ikke påbud, og at regler kombineres med holdningsarbeid i miljøer hvor sosialt press kan hemme personlig frihet.

De norske reglene om bedøving før slakting er også utfordrende for enkelte grupper og særlig da jøder. Dette hindrer jøder fra å spise norsk kjøtt, men de er sikret kjøtt som er kosher gjennom importavtaler. Dette er en kompleks problemstilling som ikke har noen enkel løsning. Noe av kritikken fra jødisk hold, med prinsipiell støtte fra Islamsk Råd og støtte på enkelte områder fra Norsk senter for menneskerettigheter og fra Likestillings- og diskrimineringsombudet, går på retten til å praktisere sin religion, ulike dyrevelferdskrav for ulike dyr gjennom tillatelse av jakt og fiske og tilrettelegging for samisk slakting, men ikke for jødisk. Ut fra en konsekvensetisk tenkemåte gjør det heller ingen forskjell om dyret slaktes i Norge eller i utlandet med tanke på dyrevelferd. Ut fra dette tankesettet kan det argumenteres for at en enten bør forby import av dyr som er slaktet uten bedøvelse, eller at man bør tillate slakt uten bedøvelse i Norge. Stålsettutvalget har kommet frem til at dagens ordning er et fungerende kompromiss mellom dyrevern og religiøse rettigheter og at 
ordningen bør videreføres. Det er allikevel et flertall for at i den hypotetiske situasjonen at import ble umuliggjort, så burde kosher slakting tillates i Norge.

Når det gjelder stereotypisering kan en kan se for seg at en som er sikh og bruker turban tar bussen til jobb. På bussen sitter det ca. 30 andre mennesker. Av disse personene er det statistisk minst tre som ikke har respekt for at han har en annen religion (Schmidt 2010). Det er ikke da utenkelig at det kommer en kommentar eller et blikk som er sårende for denne mannen eller at det skjer noe som får mannen til å føle seg bedømt ut fra sin religion, fremfor sin personlighet og væremåte. Eksempelet jeg omtalte tidligere knyttet til a bli innkalt til jobbintervju vil også kunne være tøft å bære. Det kan hevdes at en opplevelse av mistro mot sin egen religion og utseende fører til negative tanker om samfunnet og dermed til dårligere integrering.

Gjennom de ovennevnte eksemplene har vi sett at mange vil kunne føle seg urettferdig behandlet ut fra sin religion og at dette vil kunne underbygge en følelse av à være annerledes og å stå utenfor samfunnet. Dette kan hevdes å ha stor betydning for enkeltindivider og dersom mange enkeltindivider føler det samme, vil dette kunne bli en gruppering som føler seg utenfor samfunnet. Dette vil igjen kunne føre til store utfordringer også for samfunnet som helhet. En kan hevde at for å ha et mest mulig fungerende samfunn er vi avhengig av at flest mulig føler seg som en del av dette samfunnet og viser respekt ovenfor hverandres verdier og meninger.

\section{Oppsummering}

Gjennomgangen av de forskjellige eksemplene har vist at det finnes mange utfordringer knyttet til religion i et multikulturelt samfunn. Dette gjelder både for det norske samfunnet, for mindre grupperinger og på individnivå. Det ser ut til å være en økende bevissthet rundt disse utfordringene og en vilje fra statens side til å finne løsninger som er levelige både for minoritet og majoritet. Med tanken om at Norge har et uttalt mål om integrering i minne, kombinert med Skeies påstand om at ingen blir integrert uten at de selv ønsker å bli det, er respekt og toleranse viktige verdier. På enkelte områder har man kommet langt $\mathrm{i}$ å tilrettelegge for det multikulturelle, mens det på andre områder kan sies å være lengre til målet. Det er også viktig å være bevisst utfordringer knyttet til det sekulære livssyn i møte med religiøse livssyn; et multikulturelt samfunn bør ha rom for ulike religioner og livssyn. En utfordring er å gi rom for religionsutøvelse uten at andre opplever det som en krenkelse av sine verdier og sitt livssyn. Regelverk om helligdager, forsvarets reglement for uniformer og helligdager kan hevdes å være moderne eksempler til etterfølgelse. Vedrørende religiøs slakting og uniformering i politiet er det andre land enn Norge som har et regelverk bedre tilpasset et religiøst mangfold. 


\section{Referanser}

Arbeidsdepartementet (2004). Mangfold gjennom inkludering og deltakelse. (St. meld. nr. 49, 2003-2004). Henta fra www.regjeringen.no/nb/dep/ad/dok/regpubl/stmeld/2003-2004/stmeld-nr-49

Bauman, G. (1999). The Multicultural Riddle: Rethinking National, Ethnic, and Religious Identities. New York: Routledge.

Dyrevelferdsloven. (2009, Juni 19). Lov om dyrevelferd. Oslo.

Døving, C. A. (2010). Religionsplurarisme. Religion, migrasjon og integrering. Henta fra: http://www.forskningsradet.no/servlet/Satellite

Forsvaret. (2012, Juni 28). Bestemmelser om felles uniformsregler i Forsvaret. Oslo.

Jackson, R. (2003). Citizenship, religious and cultural diversity and education. I R. Jackson, International Perspectives on Citizenship, Education and Religious Diversity (ss. 1-28). London: RoutledgeFalmer.

Justis- og Beredskapsdepartementet. (1999). Ytringsfrihed bør finne sted (NOU 1999:27). Henta fra http://www.regjeringen.no/nb/dep/jd/dok/nouer/1999/nou-1999-27/7/2

Justis- og Beredskapsdepartementet. (2009, November 25). Norges 6. rapport til FNs menneskerettskomité. Henta fra

http://www.regjeringen.no/pages/38088895/CCPR_6th_Periodic_Report.pdf

Krogseth, O. (2009). Religion og Kultur. Forsøk på en forholdsbestemmelse. I A. Brunvoll, H. Bringeland, N. Gilje, \& G. Skirbekk, Religion og kultur. Ein flerfagleg samtale (ss. 32-45). Oslo: Universitetsforlaget.

Kulturdepartementet. (2013). Det livssynsåpne samfunn (NOU 2013:1). Henta fra http://www.regjeringen.no/nb/dep/kud/dok/nouer/2013/nou-2013-1/2.html.

Likestillings- og diskrimineringsombudet. (2008, Juni 16). Uttalelse i sak - Spørsmål om uniformsrelementet er $i$ strid med diskrimineringsloven. Henta fra http://www.Ido.no/Global/uttalelser/30777_1_A.pdf.

Nasjonalt Læremiddelsenter (1996). Læreplanverket for den 10-arige grunnskolen. Oslo Midtbøen, A. H., \& Rogstad, J. (2012). Diskrimineringens omfang og årsake. Etniske minoriteters tilgang til arbeidslivet. Oslo: Institutt for samfunnsforskning.

Schmidt, U. (2010). Norge: Et religiøst pluralistisk samfunn? I P. K. Botvar, \& U. Scmidt, Religion i dagens Norge. Mellom sekularisering og sakralisering (ss. 25-42). Oslo: Universitetsforlaget.

Skeie, G. (2003). Nationalism, religiosity and citizenship in Norwegian majority and minority discourses. I R. Jackson, International Perspectives on Citizenship, Education and Religious Diversity (ss. 51-66). London: RoutledgeFalmer.

Snoen, J. A. (2012, September 22). Stangs appell. Henta fra http://www.minervanett.no/stangs-appell/ den 27. April 2013.

Storhaug, H. (2012, Februar 8). Fordømmelse og udokumenterte påstander. Human Rights Service. Henta fra http://www.rights.no/2012/02/fordommelse-og-udokumenterte- pastander/

Utdanningsdirektoratet (2008). Læreplan i Religion, Livssyn og Etikk. Henta fra: http://www.udir.no/kl06/RLE1-01/

Øgstad, I. H. (2006, April 5). Norge bryter menneskerettighetene - igjen. FN-sambandet. Hentet fra http://www.fn.no/Aktuelt/Nyheter/Nyhetsarkiv/Menneskerettigheter/ 